\title{
Studi Bangkitan Perjalanan pada Pusat Perbelanjaan Jenis Minimarket yang Dilengkapi dengan Restoran
}

\author{
Frans JSS Sihombing, Nahry, R. Jachrizal Sumabrata \\ Program Studi Teknik Sipil, Fakultas Teknik, Universitas Indonesia \\ Email: fransosphere@gmail.com,nahry@eng.ui.ac.id, rjs@eng.ui.ac.id
}

\begin{abstract}
The recent phenomenon in urban life style, particularly in Jakarta, shows that people shift their place of informal meeting from their office, café or restaurant to convenience stores which are equipped by mini restaurant (resto-minimarket). Its transportation activities, i.e parking and vehicle maneuver, have caused negative impacts to the traffic flow in the vicinity of the convenience store. This research is aimed to analyse trips generated by the resto-minimarkets which are located in the city center of Jakarta. The trips were classified into people trips, motorcycle trips, and car trips. Primary data were obtained through 12 hours CCTV recording in 7 stores of study cases. Questionnaires were also carried out to the in-site costumers, as well as cyber respondents in order to confirm the variables which influence the trip attraction of resto-minimarket. Furthermore, the data were analyzed by multiple regression method. The results show that people trip attraction of resto-minimarket is affected by the area of resto-minimarket, the size of parking area, and the number of ATM (Automatic Teller Machine), while motorcycles one is affected by the number of chairs and commodity types the resto-minimarket sells. Moreover, the car trip attraction is affected by the size of parking area.
\end{abstract}

Keywords: people trip attraction, trip attraction, and resto-minimarket.

\section{Abstrak}

Perubahan gaya hidup manusia di kota-kota besar, termasuk Jakarta, saat ini menunjukkan adanya fenomena baru dimana tempat untuk melakukan pertemuan informal berpindah dari tempat kerja, café atau restoran ke mini-market yang dilengkapi dengan restoran (minimarket resto). Hal ini mengakibatkan tumbuh dengan pesatnya minimarket jenis ini di berbagai lokasi, termasuk di jalan-jalan utama di pusat kota. Di beberapa wilayah minimarket ini telah memberikan dampak negatif terhadap arus lalu lintas di sekitarnya. Studi ini dimaksudkan untuk menganalisa perjalanan yang dibangkitkan oleh minimarket jenis ini yang berlokasi di pusat bisnis di kota Jakarta. Perjalanan dikelompokkan atas perjalanan orang, perjalanan motor dan perjalanan mobil. Data perjalanan diperoleh melalui perekaman selama 12 jam menggunakan CCTV di 7 minimarket yang menjadi studi kasus. Selain itu juga dilakukan penyebaran kuesioner terhadap pengunjung minimarket yang ada di lokasi, dan juga penyebaran kuesioner melalui internet. Kuesioner dimaksudkan untuk mengkonfirmasi variabel-variabel yang mempengaruhi bangkitan perjalanan mini market ini. Selanjutnya data dianalisa menggunakan metode regresi linear berganda. Hasil pemodelan menunjukkan bahwa tarikan perjalanan orang dipengaruhi oleh luas ruang parkir dan jumlah mesin ATM, sementara bangkitan perjalanan motor dipengaruhi oleh jumlah kursi di dalam minimarket dan jumlah jenis produk yang ditawarkan. Selanjutnya, bangkitan perjalanan mobil dipengaruhi oleh luas ruang parkir.

Kata kunci: tarikan perjalanan, minimarket resto, dan bangkitan perjalanan.

\section{Pendahuluan}

Perkotaan merupakan salah satu pusat utama dari perekonomian sebuah daerah. Sebagai pusat perekonomian, transportasi di pusat perkotaan menjadi pendukung utama berjalannya roda perekonomian. Perekonomian yang semakin baik dari suatu kota mengindika- sikan masyarakat yang aktif dan produktif, dimana salah satunya ditunjukkan oleh adanya kebutuhan atas pusat perbelanjaan untuk memenuhi kebutuhan sehari-hari yang mudah dicapai dan nyaman.

Salah satu hal yang menjawab kebutuhan masyarakat ini adalah toko modern. 
Peraturan Menteri Perdagangan Republik Indonesia Nomor 68/M-DAG/PER /10/2012 tentang Waralaba untuk Jenis Usaha Toko Modern pasal 1 ayat 4 memberikan definisi bahwa "Toko modern adalah toko dengan sistem pelayanan mandiri, menjual berbagai jenis barang secara eceran yang dapat berbentuk minimarket, supermarket, departement store, hypermarket, atau grosir yang berbentuk perkulakan". Kebutuhan masyarakat yang semakin meningkat akan toko modern yang dekat dengan masyarakat dan menyediakan kenyamanan, waktu operasional 24 jam, dan kelengkapan barang yang dijual menyebabkan munculnya berbagai jenis minimarket dengan sistem retail yang tersebar di berbagai pusat kota.

Salah satu bentuk dari minimarket tersebut adalah minimarket yang berkonsep retail sekaligus restoran, yang mulai tersebar di kota-kota besar di Indonesia. Semakin maraknya cabang dari minimarket jenis restoran tersebut (selanjutnya disebut "minimarket resto") terbukti menarik perhatian masyarakat terhadap fasilitas dan berbagai kenyamanan yang ditawarkan. Namun, berkembangnya minimarket resto ini secara tidak langsung menimbulkan dampak bagi transportasi di jalan akses ke minimarket tersebut. Semakin banyak pengunjung yang mengunjungi minimarket tersebut, akan semakin banyak pula perjalanan yang dibangkitkan, demikian pula dengan kendaraan yang dibawa oleh pengunjung. Perjalanan ini terkait dengan manuver masuk, parkir, dan keluar dari area minimarket.
Tidak sesuainya jumlah pelayanan (supply) transportasi yang diberikan oleh pihak minimarket (sebagai contoh ketersediaan lahan parkir yang tidak memadai untuk menampung tarikan perjalanan yang terjadi) dikhawatirkan dapat menimbulkan area parkir di badan jalan yang tentu akan menimbulkan dampak pada arus lalu lintas. Dalam pasal 47 Peraturan Pemerintah Republik Indonesia Nomor 32 Tahun 2011 tentang Manajemen dan Rekayasa, Analisis Dampak, serta Manajemen Kebutuhan Lalu Lintas disebutkan bahwa "Setiap rencana pembangunan pusat kegiatan, permukiman, dan infrastruktur yang akan menimbulkan gangguan keamanan, keselamatan, ketertiban, dan kelancaran lalu lintas dan angkutan jalan wajib dilakukan analisis dampak lalu lintas". Potensi kemacetan yang ditimbulkan minimarket resto seperti yang dikemukakan di atas seharusnya dianalisis dampaknya sehingga tidak menimbulkan gangguan lalu lintas. Di sisi lain, adalah sebuah nilai tambah bagi pihak minimarket resto jika mampu menyediakan kebutuhan pengunjung akan berbagai sarana yang meningkatkan nilai kenyamanan.

Berdasarkan hal tersebut diperlukan kajian untuk mengatasi masalah tersebut. Sebagai langkah awal yang perlu dianalisis adalah bangkitan perjalanan yang terjadi sebagai akibat dari penempatan minimarket resto di suatu lokasi. Minimarket tersebut, sebagai tarikan (attraction) dalam kegiatan bangkitan perjalanan (trip generation), tentunya akan membangkitkan perjalanan dari berbagai pusat bangkitan di sekitarnya, 
seperti perumahan penduduk, kantor, dan bangkitan lain. Tujuan dari penelitian ini adalah menganalisis hal-hal apa saja yang mempengaruhi jumlah perjalanan yang dibangkitkan minimarket resto, dan memodelkannya menjadi sebuah persamaan yang menggambarkan pola bangkitan perjalanan tersebut, secara khusus pada minimarket resto pada kawasan bisnis di Provinsi DKI Jakarta.

\section{Metodologi}

Khisty (1990) menyatakan bahwa untuk daerah perkotaan dimungkinkan untuk menggunakan data survey untuk membentuk grafik yang menunjukkan hubungan antara persentase perjalanan dengan beberapa kategori: Home-Based Work (pekerjaan berbasis rumah), Home -Based Other (aktivitas lain berbasis rumah), dan Non-Home-Based (tidak berbasis rumah). Sebagaimana produksi perjalanan dibangun berdasarkan karak- teristik perumahan, seseorang juga dapat memperoleh tingkat tarikan perjalanan dengan menganalisa aktivitas perkotaan yang menarik perjalanan. Perjalanan tertarik ke lokasi yang bervariasi, tergantung karakter, lokasi, dan jumlah aktivitas yang terjadi di suatu zona.

Tamin (2000) menyatakan bahwa faktor-faktor yang mempengaruhi tarikan perjalanan orang adalah luas lantai untuk kegiatan industri, komersial, perkantoran, pertokoan, dan pelayanan lainnya. Faktor lain yang dapat digunakan adalah lapangan kerja dan aksesibilitas. Tarikan perjalanan dapat dimodelkan dalam model model statistik dan matematik (fungsi/persamaan) yang dapat menerangkan secara terukur beberapa aspek fisik, sosial ekonomi, atau model transportasi.

Tahap penelitian yang dilakukan dapat dilihat dalam gambar 1.

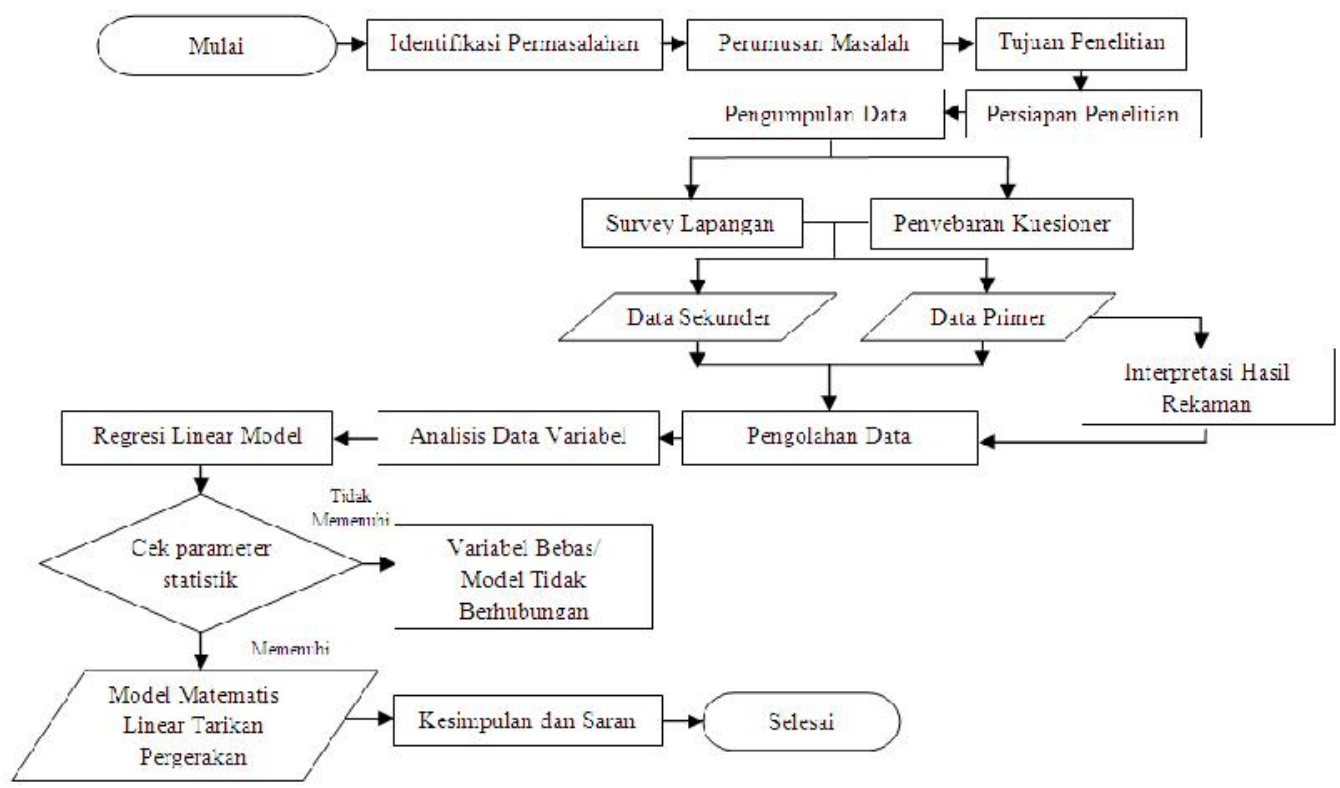

Gambar 1. Diagram Alir Metode Penelitian 
Terdapat tiga variabel terikat sebagai tarikan perjalanan yang akan dianalisis, yaitu sebagai berikut:

$\mathrm{Y}_{1}=$ tarikan perjalanan orang per jam

$\mathrm{Y}_{2}=$ tarikan perjalanan sepeda motor per jam

$\mathrm{Y}_{3}=$ tarikan perjalanan mobil per jam

Variabel bebas merupakan variabel yang diduga mempengaruhi tarikan perjalanan, yang diperoleh dari studi pustaka dan observasi lapangan. Variabel yang dipilih adalah sebagai berikut:

$\mathrm{X}_{1}=$ luas area minimarket $\left(\mathrm{m}^{2}\right)$

$\mathrm{X}_{2}=$ luas area parkir $\left(\mathrm{m}^{2}\right)$

$\mathrm{X}_{3}=$ jumlah kursi (buah)

$\mathrm{X}_{4}=$ jumlah meja (buah)

$\mathrm{X}_{5}=$ jumlah komoditas (buah)

$\mathrm{X}_{6}=$ jumlah ATM (unit)

$\mathrm{X}_{7}=$ volume kendaraan total (kend/ jam)

$\mathrm{X}_{8}=$ lebar area parkir $(\mathrm{m})$

$\mathrm{X}_{9}=$ jumlah lajur ke separator terdekat (buah)

Untuk variabel tarikan perjalanan orang per jam $\left(\mathrm{Y}_{1}\right)$, tarikan perjalanan sepeda motor per jam $\left(\mathrm{Y}_{2}\right)$, dan tarikan perjalanan mobil per jam $\left(\mathrm{Y}_{3}\right)$, pengambilan data dilakukan dengan menggunakan bantuan kamera CCTV yang dipasang sedemikian rupa untuk memantau kendaraan dan pengunjung yang datang ke minimarket. Perekaman dilakukan selama 12 jam, dimulai pukul 07.30 WIB sampai 19.30 WIB. Terdapat 7 minimarket resto yang dipilih pada berbagai kawasan bisnis, yaitu Jalan Gajah Mada (Biru-3), Jalan Hayam Wuruk (Hijau-1), Jalan RS Fatmawati (Merah-1 dan Biru-2), Jalan Mangga Besar Raya (Biru-1 dan Biru-
4), dan Jalan Taman Margasatwa Warung Jati (Hijau-2).

Variabel bebas luas bangunan $\left(\mathrm{X}_{1}\right)$, luas area parkir $\left(\mathrm{X}_{2}\right)$, jumlah kursi $\left(\mathrm{X}_{3}\right)$, jumlah meja $\left(\mathrm{X}_{4}\right)$, jumlah varian komoditas $\left(\mathrm{X}_{5}\right)$, dan jumlah ATM $\left(\mathrm{X}_{6}\right)$, diminta secara langsung pada pihak pengelola minimarket atau jika data yang diminta tidak dimiliki sementara data tersebut dapat diukur (measurable) atau dihitung (countable) secara langsung maka dilakukan pengambilan data secara langsung di lapangan. Data variabel lebar area parkir $\left(\mathrm{X}_{8}\right)$ dan jumlah lajur ke separator terdekat $\left(\mathrm{X}_{9}\right)$ diambil secara langsung di lapangan.

\section{Hasil dan Pembahasan}

\subsection{Analisa Data}

Untuk menganalisis data yang diperoleh, dilakukan dua metode, yaitu metode kuesioner dan analisis statistik. Metode kuesioner ditujukan untuk mengetahui jawaban responden acak secara kualitatif atas pertanyaan mengenai aktivitas saat mengunjungi minimarket resto serta alasan pemilihan aktivitas berdasarkan faktor-faktor yang dimiliki minimarket yang digambarkan oleh variabel terikat.

Terdapat dua model statistik yang digunakan, yaitu regresi linear berganda dan regresi linear sederhana. Regresi linear berganda digunakan jika kombinasi model antar variabel berpengaruh terdiri dari lebih dari satu variabel, sementara regresi linear sederhana digunakan jika model hanya memiliki satu variabel bebas berpengaruh. 
Bentuk umum metode analisis regresilinear-berganda adalah sebagai berikut.

$\mathrm{Y}=\mathrm{A}+\mathrm{B}_{1} \mathrm{X}_{1}+\mathrm{B}_{2} \mathrm{X}_{2}+\ldots+\mathrm{B}_{\mathrm{Z}} \mathrm{X}_{\mathrm{Z}}$

dengan:

$\mathrm{Y}=$ peubah tidak bebas

$\mathrm{X}_{1} \ldots \mathrm{X}_{\mathrm{Z}}=$ peubah bebas

$\mathrm{A} \quad=$ konstanta regresi

$\mathrm{B}_{1} \ldots \mathrm{B}_{\mathrm{Z}}=$ koefisien regresi

Metode statistik menggunakan analisis regresi linear berganda bentuk OLS

(Ordinary Least Square) dengan persyaratan model yang diperoleh dari Rietvield dan Sunaryanto (1994) serta Gujarati (2004) adalah sebagai berikut:

a. Model garis linear yang ditetapkan benar-benar sesuai dengan keadaannya.

b. Untuk regresi linear berganda, tidak terdapat kolinearitas berat antar variabel bebasnya, dibuktikan dengan nilai Condition Index $(\mathrm{CI})<30$.

c. Untuk regresi linear berganda, tidak terdapat autokorelasi, dibuktikan dengan nilai Durbin Watson mendekati 2.

d. Secara bersama-sama variabel bebas cukup signifikan mempengaruhi variabel terikat, dimana nilai $F_{\text {hitung }}>$ $F_{\text {Tabel }}$ atau nilai Sig. $<0,05$. e. Secara individual variabel bebas cukup signifikan mempengaruhi variabel terikat dengan tingkat signifikansi 90\%, dibuktikan dengan uji t dimana nilai $t_{\text {hitung }}>\mathrm{t}_{\text {Tabel }}$ atau nilai Sig. $<0,10$. Pemilihan nilai signifikansi 90\% disebabkan penelitian yang dilakukan bersifat baru dan belum ditemukan penelitian dengan topik serupa sebelumnya.

f. Tidak terjadi heteroskadistitas antar variabel bebas dan residualnya.

g. Residual tidak menggambarkan homogenitas, yakni penyebaran residual tidak berpola.

h. Memiliki nilai $R^{2}$ atau $R^{2}$ yang disesuaikan (adjusted $R^{2}$ ) dengan nilai $\mathrm{R}^{2} \geq 0,6$.

Koefisien sesuai tanda (positif/negatif) yang diharapkan, logis, dan sesuai dengan kenyataan. Hasil dari pengumpulan data dapat dilihat pada tabel 1 .

\subsection{Analisis Kuesioner}

Kuesioner disebarkan melalui media internet maupun secara langsung pada responden di lokasi studi. Selanjutnya, jawaban dari 110 responden via internet dan 37 responden langsung dianalisis secara deskriptif.

Tabel 1. Rekapitulasi Data Variabel Bebas dan Variabel Terikat Sampel

\begin{tabular}{cccccccccccccc}
\hline Minimarket & $\begin{array}{c}\mathrm{Y}_{1} \\
(\mathrm{org})\end{array}$ & $\begin{array}{c}\mathrm{Y}_{2} \\
(\mathrm{kend})\end{array}$ & $\begin{array}{c}\mathrm{Y}_{3} \\
(\mathrm{kend})\end{array}$ & $\begin{array}{c}\mathrm{X}_{1} \\
\left(\mathrm{~m}^{2}\right)\end{array}$ & $\begin{array}{c}\mathrm{X}_{2} \\
\left(\mathrm{~m}^{2}\right)\end{array}$ & $\begin{array}{c}\mathrm{X}_{3} \\
(\mathrm{bh})\end{array}$ & $\begin{array}{c}\mathrm{X}_{4} \\
(\mathrm{bh})\end{array}$ & $\begin{array}{c}\mathrm{X}_{5} \\
(\mathrm{bh})\end{array}$ & $\begin{array}{c}\mathrm{X}_{6} \\
(\text { unit })\end{array}$ & $\begin{array}{c}\mathrm{X}_{7} \\
(\mathrm{kend} / \mathrm{jam})\end{array}$ & $\begin{array}{c}\mathrm{X}_{8} \\
(\mathrm{~m})\end{array}$ & $\begin{array}{c}\mathrm{X}_{9} \\
(\text { lajur })\end{array}$ \\
\hline MERAH-1 & 24,3 & 3,83 & 4,08 & 136 & 81 & 37 & 18 & 13 & 1 & 2536 & 13,5 & 2 \\
\hline BIRU-1 & 21 & 5,17 & 0,5 & 144,05 & 21,33 & 45 & 12 & 13 & 1 & 4907 & 10 & 1 \\
\hline BIRU-2 & 29,5 & 5,75 & 2 & 289,16 & 70 & 54 & 17 & 15 & 1 & 2418 & 10 & 2 \\
\hline BIRU-3 & 31,5 & 7,08 & 1,92 & 323,84 & 38,5 & 58 & 16 & 15 & 2 & 9343 & 11 & 3 \\
\hline BIRU-4 & 32,7 & 8,75 & 4,3 & 352,25 & 96,5 & 136 & 34 & 16 & 1 & 3245 & 17,5 & 2 \\
\hline HIJAU-1 & 38,25 & 7,92 & 1,25 & 377,28 & 80 & 82 & 20 & 17 & 2 & 5952 & 10 & 3 \\
\hline HIJAU-2 & 33 & 5,83 & 5,58 & 217,8 & 132 & 34 & 9 & 17 & 2 & 3426 & 16,5 & 2 \\
\hline
\end{tabular}


Untuk mengetahui faktor-faktor utama yang mempengaruhi kedatangan ke minimarket resto, responden ditanyakan mengenai alasan kedatangan ke minimarket yang terakhir mereka kunjungi. Pertanyaan mengenai alasan dibagi dua, yaitu alasan utama dan alasan sampingan. Untuk pertanyaan alasan utama kedatangan, responden hanya boleh memilih satu jawaban, sementara untuk pertanyaan alasan sampingan, responden boleh memilih lebih dari satu. Dari hasil pengolahan data diperoleh pembelian sebagai alasan utama dengan persentase terbesar yaitu $65 \%$, disusul dengan 'nongkrong' (28\%), penggunaan ATM (4\%), dan fasilitas Wifi (3\%). Sementara itu 54 dari 147 responden memilih 'nongkrong' sebagai alasan sampingan, disusul pembelian dengan 42 responden, fasilitas wifi dengan 31 responden, dan penggunaan ATM 26 responden. Grafik perbandingan responden berdasarkan alasan utama dan alasan sampingan kedatangan dapat dilihat berturut-turut pada gambar 2 dan 3 .

Secara rasional, pembelian komoditas di minimarket berkaitan dengan jumlah komoditas yang dijual dan fasilitas untuk mengonsumsi barang yang bisa langsung dikonsumsi di minimarket. Akibatnya, tingginya jumlah responden yang melakukan pembelian dapat menunjukkan bahwa variabel bebas jumlah komoditas $\left(\mathrm{X}_{5}\right)$ berpengaruh pada kedatangan dengan alasan pembelian. Hal ini disebabkan jumlah komoditas yang semakin banyak akan memberikan pilihan berbelanja yang semakin banyak.

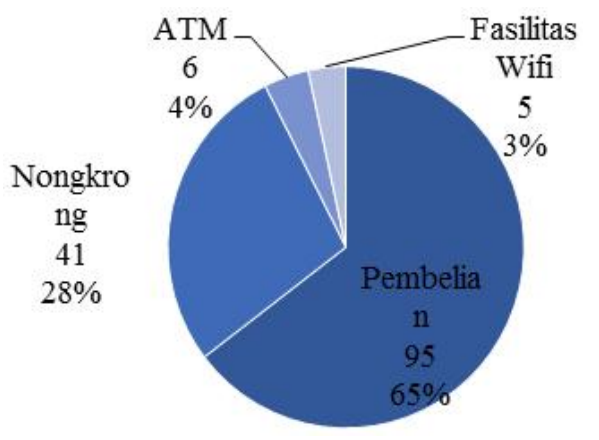

Gambar 2. Grafik Perbandingan Jumlah Responden Berdasarkan Alasan Utama Kedatangan

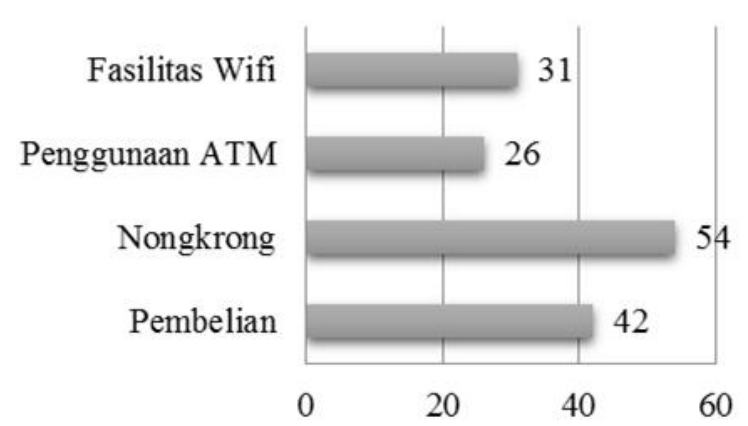

Gambar 3. Grafik Jumlah Responden Berdasarkan Alasan Sampingan Kedatangan

Untuk melihat pengaruh fasilitas untuk mengonsumsi barang yang bisa langsung dikonsumsi di minimarket, perlu dilihat perilaku pengunjung (yang diwakili responden) mengenai hal tersebut. Berdasarkan hasil olahan data, mengkonsumsi barang yang dibeli di tempat (on the spot) dilakukan oleh $69 \%$ responden, sementara $31 \%$ tidak mengonsumsi di tempat (take away). Grafik perbandingan pola penggunaan/konsumsi barang yang dibeli dapat dilihat dalam gambar 4. Dari gambar 4 terlihat bahwa $69 \%$ responden mengkonsumsi barang yang dibelinya di dalam minimarket tersebut.

Besarnya perbandingan responden yang melakukan konsumsi di tempat secara 
rasional menunjukkan bahwa fasilitas untuk melakukan konsumsi di tempat, seperti luas area minimarket $\left(\mathrm{X}_{1}\right)$, jumlah kursi $\left(X_{3}\right)$, dan jumlah meja $\left(X_{4}\right)$ mempengaruhi kedatangan dengan alasan pembelian.

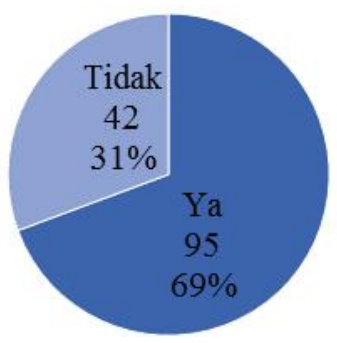

Gambar 4. Grafik Perbandingan Jumlah Konsumen Berdasarkan Jumlah Konsumen yang Mengkonsumsi Pembeliannya di Tempat

Terkait dengan alasan sampingan kedatangan konsumen ke minimarket, 'Nongkrong' dan 'fasilitas Wifi' menjadi alasan tertinggi kedua. Oleh karena itu, diperlukan analisis mengenai lama 'nongkrong' serta alasan pengunjung memilih minimarket resto sebagai tempat 'nongkrong'.

Responden ditanyakan mengenai durasi 'nongkrong' saat kunjungan terakhir ke minimarket resto dalam satuan jam. Interval durasi 'nongkrong' dibagi menjadi lima, dan hasilnya $15 \%$ dari total 98 responden yang melakukan 'nongkrong', melakukannya selama setengah jam, 49\% selama setengah jam sampai satu jam, 19\% selama satu sampai dua jam, 16\% selama dua sampai lima jam, dan $1 \%$ di atas lima jam. Grafik perbandingan dapat dilihat dalam gambar 5.

Selanjutnya, responden ditanyakan mengenai alasan untuk 'nongkrong' di minimarket resto, yang tentunya menja- di alasan mengapa mereka datang ke minimarket tersebut. Dari 98 responden yang melakukan 'nongkrong', 63 responden memilih alasan area minimarket yang luas dan memadai, selanjutnya 79 responden beralasan minimarket resto menyediakan kursi dan meja, 31 responden mengatakan karena minimarket resto menyediakan fasilitas wifi, 45 responden 'nongkrong' karena bisa sambil belanja di tempat 'tongkrongannya' di minimarket, 50 responden menjawab karena suhu minimarket yang nyaman, dan 29 responden memilih menjawab karena minimarket menyediakan stop kontak untuk charger gadget. Grafik jumlah responden berdasarkan alasan 'nongkrong' dapat dilihat pada Gambar 6.

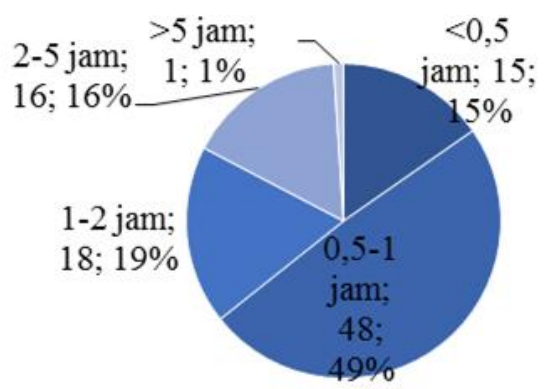

Gambar 5. Perbandingan jumlah responden berdasarkan durasi 'nongkrong'

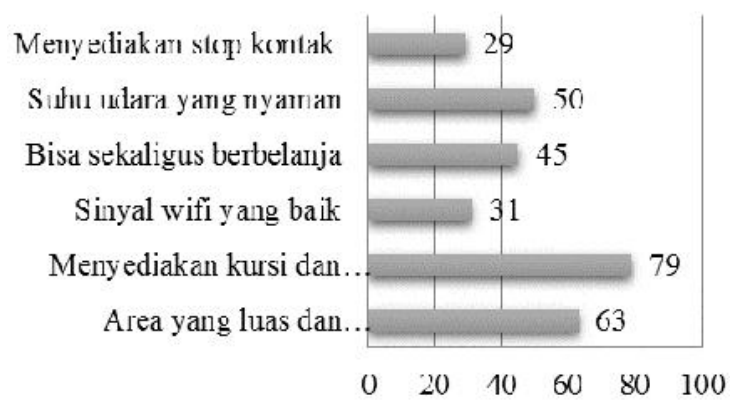

Gambar 6. Grafik Jumlah Responden Berdasarkan Alasan Melakukan 'nongkrong' 
Dari gambar 6, dapat disimpulkan bahwa responden yang melakukan 'nongkrong' memilih area yang luas dan memadai (63\%) serta penyediaan kursi dan meja oleh minimarket (79\%) sebagai alasan 'nongkrong'. Berdasarkan hasil tersebut, maka secara rasional hasil kuesioner mendukung bahwa variabel bebas jumlah kursi $\left(\mathrm{X}_{3}\right)$, jumlah meja $\left(\mathrm{X}_{4}\right)$, dan luas area minimarket $\left(\mathrm{X}_{1}\right)$ mempengaruhi kedatangan pengunjung dengan alasan 'nongkrong' ke minimarket resto. Walaupun Suhu udara yang nyaman menempati peringkat tiga, namun dari ketujuh sampel survey terlihat bahwa $100 \%$ minimarket restoran memiliki pendingin ruangan. Oleh karenanya, variabel terkait suhu udara tidak diperhitungkan dalam model. Di peringkat empat, hampir 50\% pengunjung beralasan bisa sekaligus berbelanja, sehingga faktor jumlah komoditas $\left(\mathrm{X}_{5}\right)$ juga mempengaruhi kedatangan pengunjung dengan alasan 'nongkrong' ke minimarket resto.

Selanjutnya, sejumlah 67 responden acak via internet menjawab pertanyaan terkait segi transportasi ke minimarket resto. Responden ditanyakan mengenai harapan dari segi transportasi. Hasilnya, 36 dari 67 responden menjawab area parkir yang luas, dilanjutkan dengan 33 dari 67 menjawab aksesibilitas minimarket yang mudah, 26 dari 67 menjawab lalu lintas di depan minimarket lancar, dan 20 dari 67 menjawab lebar lapangan parkir yang besar sehingga kendaraan mudah masuk. Hasil ini digambarkan pada gambar 7 .

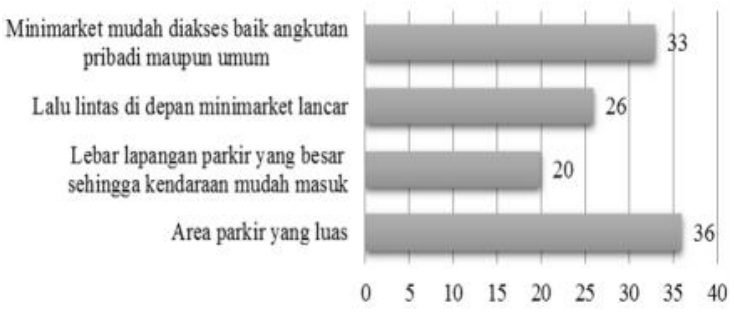

Gambar 7. Grafik Jumlah Responden Berdasarkan Harapan pada Minimarket Restoran di Bidang Transportasi

Dari hasil analisis tersebut, harapanharapan di atas dapat disimpulkan sebagai faktor-faktor yang mempengaruhi kedatangan pengunjung terutama kedatangan kendaraan, baik sepeda motor ataupun mobil. Dalam penelitian ini, area Aksesibilitas minimarket secara rasional dapat diartikan sebagai kemudahan pengunjung (dari jalan raya yang dilintasi) untuk dapat menemukan minimarket resto, mendapatkan jarak pandang yang baik dan memiliki kemudahan untuk berpindah jalur, dengan salah satu yang dinilai menghalangi adalah separator jalan. Selain itu, dengan semakin banyaknya lajur maka semakin banyak kendaraan yang melintas sehingga meningkatkan parkir yang luas digambarkan oleh variabel bebas luas area parkir $\left(\mathrm{X}_{2}\right)$ peluang kedatangan yang tidak direncanakan sebelumnya. Oleh karena itu, kedua penjelasan tersebut dapat dikaitkan dengan jumlah lajur ke separator $\left(\mathrm{X}_{9}\right)$.

Selanjutnya, lebar area parkir yang besar digambarkan dalam variabel bebas lebar area parkir $\left(\mathrm{X}_{8}\right)$. Sementara lalu lintas di depan minimarket yang lancar secara tidak langsung juga dipengaruhi oleh jumlah lajur ke separator terdekat dan manuver keluarmasuk kendaraaan yang dipengaruhi 
oleh luas area parkir dan lebar area parkir.

\subsection{Analisis Statistik Data}

Analisis korelasi diperlukan untuk menentukan tingkat keeratan antar variabel, baik antara variabel terikat dengan variabel bebas, serta antara suatu variabel bebas dengan variabel bebas lainnya. Hasil analisis tersebut diperlihatkan pada tabel 2 .

Angka bercetak tebal pada tabel 2 memperlihatkan nilai korelasi variabelvariabel yang memiliki korelasi cukup kuat $(r \geq 0,5)$ yaitu sebagai berikut:
- Tarikan perjalanan orang per jam $\left(\mathrm{Y}_{1}\right)$ berkorelasi cukup kuat dengan luas area minimarket $\left(\mathrm{X}_{1}\right)$, luas area parkir $\left(\mathrm{X}_{2}\right)$, jumlah komoditas $\left(\mathrm{X}_{5}\right)$, jumlah unit ATM $\left(\mathrm{X}_{6}\right)$, dan jumlah lajur ke separator $\left(\mathrm{X}_{9}\right)$.

- Tarikan perjalanan sepeda motor per jam $\left(\mathrm{Y}_{2}\right)$ berkorelasi cukup kuat dengan luas area minimarket $\left(\mathrm{X}_{1}\right)$, jumlah kursi $\left(\mathrm{X}_{3}\right)$, jumlah meja $\left(\mathrm{X}_{4}\right)$, jumlah komoditas $\left(\mathrm{X}_{5}\right)$, dan jumlah lajur ke separator $\left(\mathrm{X}_{9}\right)$.

Tarikan perjalanan mobil per jam $\left(\mathrm{Y}_{3}\right)$ berkorelasi cukup kuat dengan luas area parkir $\left(\mathrm{X}_{2}\right)$ dan lebar area parkir $\left(\mathrm{Y}_{8}\right)$

Tabel 2. Tabel Nilai korelasi ( $r$ ) antar Variabel

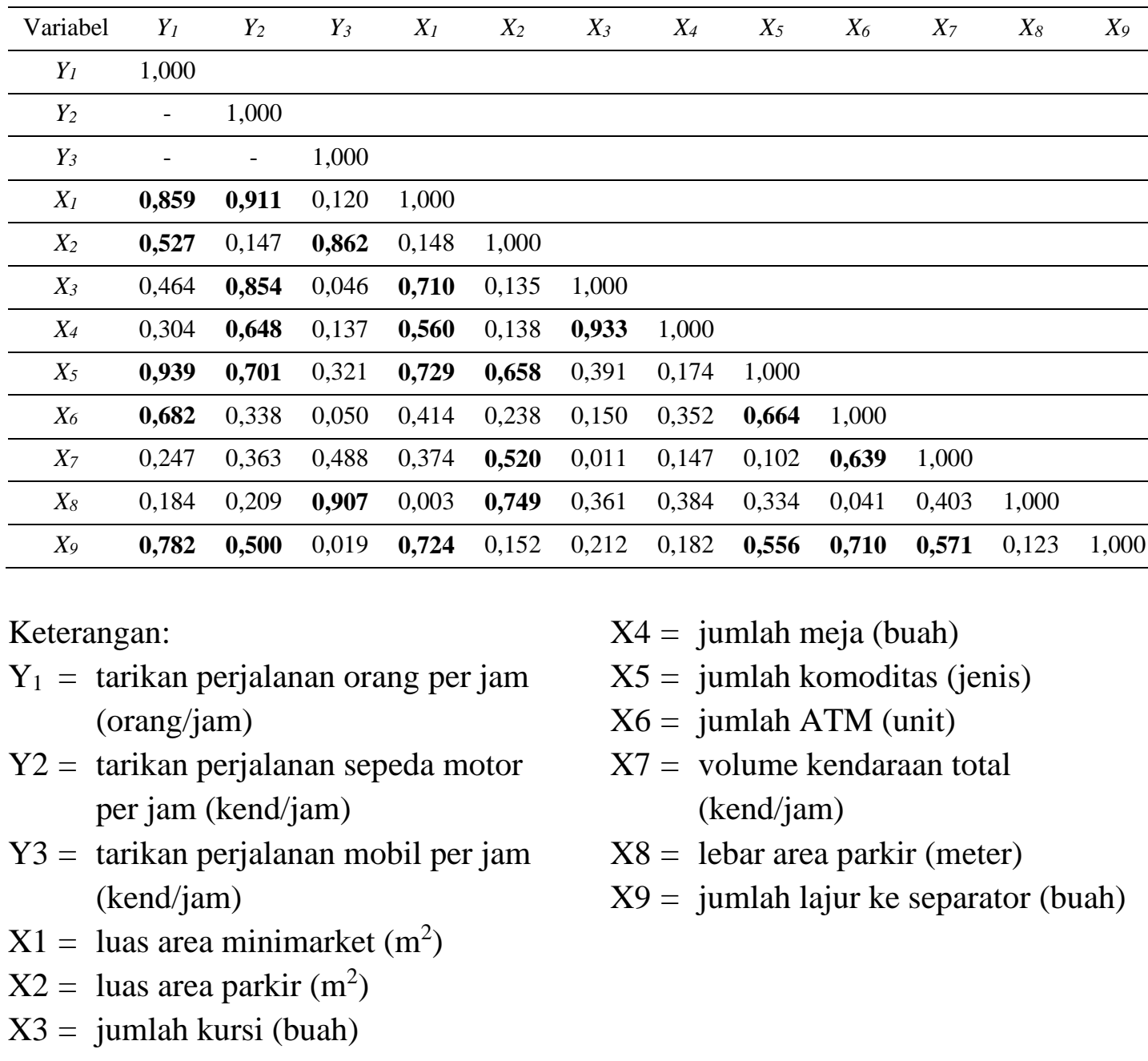




\subsection{Pemodelan Tarikan Perjalanan}

\subsubsection{Pemodelan Tarikan Perjalanan orang}

Dari lima variabel yang memiliki korelasi cukup kuat dengan tarikan perjalanan orang per jam, dilakukan kombinasi model untuk kemudian diseleksi dengan parameter statistik yang telah dijelaskan. Terdapat 14 kombinasi model, yaitu:

Model A1 : $\mathrm{Y}_{1}=\mathrm{A}+\mathrm{B}_{1} \cdot \mathrm{X}_{1}+\mathrm{B}_{2} . \mathrm{X}_{2}+$ $\mathrm{B}_{3} . \mathrm{X}_{5}+\mathrm{B}_{4} \cdot \mathrm{X}_{6}+\mathrm{B}_{5}$ $\mathrm{X}_{9}$

Model A2 : $Y_{1}=A+B_{1} . X_{1}+B_{2} . X_{2}+$ $B_{3} . X_{5}+B_{4} \cdot X_{6}$

Model A3 : $Y_{1}=A+B_{1} . X_{1}+B_{2} . X_{2}+$ $\mathrm{B}_{3} . \mathrm{X}_{5}+\mathrm{B}_{4} \cdot \mathrm{X}_{9}$

Model A4 : $\mathrm{Y}_{1}=\mathrm{A}+\mathrm{B}_{1} . \mathrm{X}_{1}+\mathrm{B}_{2} . \mathrm{X}_{2}+$ $\mathrm{B}_{3} . \mathrm{X}_{6}+\mathrm{B}_{4} \cdot \mathrm{X}_{9}$

Model A5 : $\mathrm{Y}_{1}=\mathrm{A}+\mathrm{B}_{1} . \mathrm{X}_{2}+\mathrm{B}_{2} . \mathrm{X}_{5}+$ $B_{3} . X_{6}+B_{4} \cdot X_{9}$

Model A6 : $Y_{1}=A+B_{1} . X_{1}+B_{2} . X_{2}+$ $\mathrm{B}_{3} . \mathrm{X}_{5}$

Model A7 : $\mathrm{Y}_{1}=\mathrm{A}+\mathrm{B}_{1} . \mathrm{X}_{1}+\mathrm{B}_{2} . \mathrm{X}_{2}+$ $\mathrm{B}_{3} . \mathrm{X}_{6}$

Model A8 : $\mathrm{Y}_{1}=\mathrm{A}+\mathrm{B}_{1} . \mathrm{X}_{1}+\mathrm{B}_{2} . \mathrm{X}_{2}+$ B. $X_{9}$

Model A9 : $\mathrm{Y}_{1}=\mathrm{A}+\mathrm{B}_{1} . \mathrm{X}_{1}+\mathrm{B}_{2} . \mathrm{X}_{5}+$ $\mathrm{B}_{3} . \mathrm{X}_{6}$

Model A10: $Y_{1}=A+B_{1} \cdot X_{1}+B_{2} . X_{5}+$ $\mathrm{B}_{3} . \mathrm{X}_{9}$

Model A11: $Y_{1}=A+B_{1} . X_{1}+B_{2} . X_{6}+$ B. $X_{9}$

Model A12: $\mathrm{Y}_{1}=\mathrm{A}+\mathrm{B}_{1} . \mathrm{X}_{2}+\mathrm{B}_{2} . \mathrm{X}_{5}+$ $\mathrm{B}_{3} . \mathrm{X}_{6}$
Model A13: $Y_{1}=A+B_{1} \cdot X_{2}+B_{2} . X_{5}+$ $\mathrm{B}_{3} . \mathrm{X}_{9}$

Model A14: $Y_{1}=A+B_{1} . X_{5}+B_{2} . X_{6}+$ $\mathrm{B}_{3} . \mathrm{X}_{9}$

Berdasarkan berbagai uji yang telah dilakukan untuk menyeleksi 14 kombinasi model, terpilih satu model akhir yang lolos semua parameter dan dipilih sebagai model terbaik, yaitu model A7. Hasil akhir uji statistik model terpilih dapat dilihat dalam tabel 3 .

\subsubsection{Pemodelan Tarikan Perjalanan Sepeda Motor}

Dari lima variabel yang memiliki korelasi cukup kuat dengan tarikan perjalanan sepeda motor per jam, dilakukan kombinasi model untuk kemudian diseleksi dengan parameter statistik yang telah dijelaskan. Terdapat 25 kombinasi model, yaitu:

Model B1: $\mathrm{Y}_{2}=\mathrm{A}+\mathrm{B}_{1} . \mathrm{X}_{1}+\mathrm{B}_{2} . \mathrm{X}_{3}+$ $\mathrm{B}_{3} . \mathrm{X}_{4}+\mathrm{B}_{4} \cdot \mathrm{X}_{5}+\mathrm{B}_{5}$ $\mathrm{X}_{9}$

Model B2: $Y_{2}=A+B_{1} . X_{1}+B_{2} . X_{3}+$ $\mathrm{B}_{3} . \mathrm{X}_{4}+\mathrm{B}_{4} \cdot \mathrm{X}_{5}$

Model B3: $\mathrm{Y}_{2}=\mathrm{A}+\mathrm{B}_{1} . \mathrm{X}_{1}+\mathrm{B}_{2} . \mathrm{X}_{3}+$ $\mathrm{B}_{3} . \mathrm{X}_{4}+\mathrm{B}_{4} \cdot \mathrm{X}_{9}$

Model B4: $\mathrm{Y}_{2}=\mathrm{A}+\mathrm{B}_{1} \cdot \mathrm{X}_{1}+\mathrm{B}_{2} . \mathrm{X}_{3}+$ $\mathrm{B}_{3} . \mathrm{X}_{5}+\mathrm{B}_{4} \cdot \mathrm{X}_{9}$

Model B5: $Y_{2}=A+B_{1} . X_{3}+B_{2} . X_{4}+$ $\mathrm{B}_{3} . \mathrm{X}_{5}+\mathrm{B}_{4} . \mathrm{X}_{9}$

Tabel 3. Hasil Uji Statistik Model Tarikan Perjalanan Orang Terpilih

\begin{tabular}{|c|c|c|c|c|c|c|c|c|c|c|}
\hline \multirow{2}{*}{ Model } & \multirow{2}{*}{$\begin{array}{c}\text { Kombinasi } \\
\text { Variabel }\end{array}$} & \multirow{2}{*}{ B } & \multicolumn{2}{|c|}{ ANOVA } & \multicolumn{2}{|c|}{ Uji t } & \multirow[t]{2}{*}{$\mathrm{R}^{2}$} & \multirow{2}{*}{$\begin{array}{l}\text { Condition } \\
\text { Index }\end{array}$} & \multirow{2}{*}{$\begin{array}{c}\text { Heteros- } \\
\text { kedastisitas }\end{array}$} & \multirow{2}{*}{$\begin{array}{l}\text { Durbin } \\
\text { Watson }\end{array}$} \\
\hline & & & $\mathrm{F}$ & Sig & $\mathrm{t}$ & Sig & & & & \\
\hline \multirow{4}{*}{ A7 } & Constant & 10.538 & \multirow{4}{*}{54.964} & \multirow{4}{*}{0.004} & 6.608 & 0.007 & \multirow{4}{*}{0.982} & \multirow{4}{*}{8,73} & \multirow{4}{*}{$\begin{array}{c}\text { Lolos (sig. } \mathrm{t} \\
\min = \\
0.220)\end{array}$} & \multirow{4}{*}{2.419} \\
\hline & X1 & 0.040 & & & 7.947 & 0.004 & & & & \\
\hline & $\mathrm{X} 2$ & 0.055 & & & 4.406 & 0.022 & & & & \\
\hline & $\mathrm{X} 6$ & 3.453 & & & 3.694 & 0.034 & & & & \\
\hline
\end{tabular}


Model B6: $\mathrm{Y}_{2}=\mathrm{A}+\mathrm{B}_{1} \cdot \mathrm{X}_{1}+\mathrm{B}_{2} . \mathrm{X}_{3}+$ $\mathrm{B}_{3} . \mathrm{X}_{4}$

Model B7: $Y_{2}=A+B_{1} \cdot X_{1}+B_{2} . X_{3}+$ $\mathrm{B}_{3} . \mathrm{X}_{5}$

Model B8: $\mathrm{Y}_{2}=\mathrm{A}+\mathrm{B}_{1} \cdot \mathrm{X}_{1}+\mathrm{B}_{2} \cdot \mathrm{X}_{3}+$ $\mathrm{B}_{3} . \mathrm{X}_{9}$

Model B9: $Y_{2}=A+B_{1} . X_{1}+B_{2} . X_{4}+$ $\mathrm{B}_{3} . \mathrm{X}_{5}$

Model B10: $Y_{2}=A+B_{1} . X_{1}+B_{2} . X_{4}+$ $\mathrm{B}_{3} . \mathrm{X}_{9}$

Model B11: $Y_{2}=A+B_{1} . X_{1}+B_{2} . X_{5}+$ $\mathrm{B}_{3} . \mathrm{X}_{9}$

Model B12: $Y_{2}=A+B_{1} . X_{3}+B_{2} . X_{4}+$ $\mathrm{B}_{3} . \mathrm{X}_{5}$

Model B13: $\mathrm{Y}_{2}=\mathrm{A}+\mathrm{B}_{1} . \mathrm{X}_{3}+\mathrm{B}_{2} . \mathrm{X}_{4}+$ $\mathrm{B}_{3} . \mathrm{X}_{9}$

Model B14: $Y_{2}=A+B_{1} . X_{4}+B_{2} . X_{5}+$ $\mathrm{B}_{3} . \mathrm{X}_{9}$

Model B15: $Y_{2}=A+B_{1} . X_{1}+B_{2} . X_{3}$

Model B16: $\mathrm{Y}_{2}=\mathrm{A}+\mathrm{B}_{1} . \mathrm{X}_{3}+\mathrm{B}_{2} . \mathrm{X}_{5}$

Model B17: $Y_{2}=A+B_{1} \cdot X_{1}+B_{2} \cdot X_{4}$

Model B18: $Y_{2}=A+B_{1} \cdot X_{1}+B_{2} . X_{5}$

Model B19: $Y_{2}=A+B_{1} . X_{1}+B_{2} . X_{9}$

Model B20: $\mathrm{Y}_{2}=\mathrm{A}+\mathrm{B}_{1} . \mathrm{X}_{3}+\mathrm{B}_{2} . \mathrm{X}_{5}$

Model B21: $Y_{2}=A+B_{1} . X_{4}+B_{2} . X_{5}$

Model B22: $Y_{2}=A+B_{1} . X_{4}+B_{2} . X_{9}$

Model B23: $Y_{2}=A+B_{1} . X_{5}+B_{2} . X_{9}$

Model B24: $Y_{2}=B_{1} . X_{3}+B_{2} . X_{5}$
Model B25: $\mathrm{Y}_{2}=\mathrm{B}_{1} . \mathrm{X}_{4}+\mathrm{B}_{2} . \mathrm{X}_{5}$

Berdasarkan berbagai uji yang telah dilakukan untuk menyeleksi 25 kombinasi model, terpilih satu model akhir yang lolos semua parameter dan dipilih sebagai model terbaik, yaitu model B24. Hasil akhir uji statistik model terpilih dapat dilihat dalam tabel 4 .

\subsubsection{Pemodelan Tarikan Perjalanan Mobil}

Dari tiga variabel yang memiliki korelasi cukup kuat dengan tarikan perjalanan mobil per jam, dilakukan kombinasi model untuk kemudian diseleksi dengan parameter statistik yang telah dijelaskan. Terdapat 4 kombinasi model, yaitu: Model C1: $\mathrm{Y}_{3}=\mathrm{A}+\mathrm{B}_{1} . \mathrm{X}_{2}+\mathrm{B}_{2} . \mathrm{X}_{8}$

Model C2: $\mathrm{Y}_{3}=\mathrm{A}+\mathrm{B} \cdot \mathrm{X}_{2}$ Model C3: $\mathrm{Y}_{3}=\mathrm{A}+\mathrm{B} . \mathrm{X}_{8}$ Model C4: $\mathrm{Y}_{3}=\mathrm{B} . \mathrm{X}_{2}$

Berdasarkan berbagai uji yang telah dilakukan untuk menyeleksi 4 kombinasi model, terpilih satu model akhir yang lolos semua parameter dan dipilih sebagai model terbaik, yaitu model $\mathrm{C} 4$. Hasil akhir uji statistik model terpilih dapat dilihat dalam tabel 5 .

Tabel 4. Hasil Uji Statistik Model Tarikan Perjalanan Sepeda Motor Terpilih

\begin{tabular}{|c|c|c|c|c|c|c|c|c|}
\hline \multirow{2}{*}{ Model } & \multirow{2}{*}{$\begin{array}{c}\text { Kombinasi } \\
\text { Variabel }\end{array}$} & \multirow{2}{*}{ B } & \multicolumn{2}{|c|}{ Uji t } & \multirow{2}{*}{$\mathrm{R}^{2}$} & \multirow{2}{*}{$\begin{array}{l}\text { Condition } \\
\text { Index }\end{array}$} & \multirow{2}{*}{$\begin{array}{c}\text { Heteros- } \\
\text { kedastisitas }\end{array}$} & \multirow{2}{*}{$\begin{array}{l}\text { Durbin } \\
\text { Watson }\end{array}$} \\
\hline & & & $\mathbf{t}$ & Sig & & & & \\
\hline \multirow{3}{*}{ B24 } & Constant & & & & \multirow{3}{*}{0.992} & \multirow{3}{*}{4.395} & \multirow{3}{*}{$\begin{array}{l}\text { Lolos (sig. t } \\
\min =0.398 \text { ) }\end{array}$} & \multirow{3}{*}{2.154} \\
\hline & $\mathrm{X} 3$ & 0.034 & 4.117 & 0.009 & & & & \\
\hline & $\mathrm{X} 5$ & 0.277 & 7.113 & 0.001 & & & & \\
\hline
\end{tabular}

Tabel 5. Hasil Uji Statistik Model Tarikan Perjalanan Mobil Terpilih

\begin{tabular}{|c|c|c|c|c|c|c|c|}
\hline \multirow{2}{*}{ Model } & \multirow{2}{*}{ Variabel } & \multirow{2}{*}{ B } & \multicolumn{2}{|c|}{ Uji t } & \multirow{2}{*}{$\begin{array}{c}\mathrm{F} \\
\text { (sig.) }\end{array}$} & \multirow{2}{*}{$\mathrm{R}^{2}$} & \multirow{2}{*}{ Heteroskedastisitas } \\
\hline & & & $\mathrm{t}$ & Sig, & & & \\
\hline \multirow{2}{*}{ C4 } & Constant & & & & \multirow{2}{*}{0.000} & \multirow{2}{*}{0.927} & \multirow{2}{*}{$\begin{array}{c}\text { Lolos (sig. } \mathrm{t} \min = \\
0.339)\end{array}$} \\
\hline & $\mathrm{X}_{2}$ & 0.034 & 8.759 & 0.000 & & & \\
\hline
\end{tabular}




\section{Simpulan}

Model tarikan perjalanan orang per jam pada minimarket resto dapat dimodelkan dengan persamaan:

$\mathrm{Y}_{1}=10,538+0,040 \mathrm{X}_{1}+0,055 \mathrm{X}_{2}+$ $3,453 \mathrm{X}_{6}\left(\mathrm{R}^{2}=0,982\right)$

Dimana:

$\mathrm{Y}_{1}=$ tarikan perjalanan orang per jam (orang/jam)

$\mathrm{X}_{1}=$ luas area minimarket $\left(\mathrm{m}^{2}\right)$

$\mathrm{X}_{2}=$ luas area parkir $\left(\mathrm{m}^{2}\right)$

$\mathrm{X}_{6}=$ jumlah ATM (unit)

Model tarikan perjalanan sepeda motor per jam pada minimarket resto dapat dimodelkan dengan persamaan:

$\mathrm{Y}_{2}=0,034 \mathrm{X}_{3}+0,277 \mathrm{X}_{5}\left(\mathrm{R}^{2}=0,992\right)$

Dimana:

$\mathrm{Y}_{2}=$ tarikan perjalanan sepeda motor per jam (kendaraan/jam)

$\mathrm{X}_{3}=$ jumlah kursi (buah)

$\mathrm{X}_{5}=$ jumlah komoditas (jenis)

Model tarikan perjalanan mobil per jam pada minimarket resto dapat dimodelkan dengan persamaan:

$\mathrm{Y}_{3}=0,034 \mathrm{X}_{2}\left(\mathrm{R}^{2}=0,927\right)$

Dimana:

$\mathrm{Y}_{3}=$ tarikan perjalanan mobil per jam (kendaraan/jam)

$\mathrm{X}_{2}=$ luas area parkir $\left(\mathrm{m}^{2}\right)$

\section{Daftar Pustaka}

Gujarati, D., 2004. Basic Econometric. Mc-Grawhill, New York.

Khisty, C. Jotin. 1990. Transportation Engineering: An Introduction. New Jersey: Prentice-Hall, Inc.

Menteri Perdagangan Republik Indonesia. Peraturan Nomor 68/ $M$ DAG/PER/10/2012 tentang Wa- ralaba untuk Jenis Usaha Toko Modern. Jakarta.

Peraturan Pemerintah Republik Indonesia Nomor 32 Tahun 2011 tentang Manajemen dan Rekayasa, Analisis Dampak, serta Manajemen Kebutuhan Lalu Lintas. Jakarta.

Rietveld, Piet dan Lasmono Tri Sunaryanto. 1994. 87 Masalah Pokok Dalam Regresi Berganda, Edisi Pertama. Yogyakarta: Andi Offset.

Tamin, Ofyar Z., 2000. Perancangan dan Pemodelan Transportasi. Bandung: Institut Teknologi Bandung. 